\title{
RUNTUHNYA DUNIA SOSIAL DI ERA KOMUNIKASI MEDIA SIMULAKRA
}

\author{
Nazar Naamy \\ Email: nazarnaamy72@uinmataram.ac.id
}

\begin{abstract}
Contemporary century humans live in the chaotic ecstasy of communication, along with the disappearance of private space. Public space is no longer a spectacle and private space is no longer a secret. The difference between the inside and the outside is erased along with the ambiguous boundary between public space and private space. The most intimate life, now a life support for virtual media. The media that support contemporary human life today have an impact on simulacra that influences the mind as if the virtual world of the media is real without presenting original reality essentially and finally simulacra can control humans by trapping them to believe that simulation is real and also to make humans dependent on simulation and can't live without it. The world like this is a concept introduced by Jean Baudrillard which represents no longer the boundary between the real and the false, so that it impacts on the collapse of human social life because it is no longer able to socialize due to the media. Human life will be divided into individuals who carry out activities that they unwittingly distance from each other, and result in a lack of close relations between the people directly. So at that time human social life experienced a collapse caused by the era of media communication simulcra.
\end{abstract}

Keywords: Collapse of the Social World, Media Communication, Simulakra 


\begin{abstract}
Abstrak
Manusia abad kontemporer hidup dalam ekstasi komunikasi yangkacau, seiring dengan lenyapnya ruang privat. Ruang publik tak lagi menjadi tontonan dan ruang privat tak lagi menjadi rahasia. Perbedaan antara bagian dalam dan bagian luar terhapus seiring dengan rancunya batas antara ruang publik dan ruang privat. Kehidupan yang paling intim, sekarang menjadi penopang hidup virtual media. Media yang menjadi penopang kehidupan manusia kontemporer saat ini berdampak pada simulakra yang mempengaruhi pikiran seolah-olah dunia virtual media itu nyata yang tanpamenghadirkan realitas aslinya secara esensial dan akhirnya simulakra mampu mengontrol manusia dengan menjebak mereka untuk percaya bahwa simulasi itu nyata dan juga untuk membuat manusia tergantung pada simulasi dan tidak bisa hidup tanpanya. Dunia seperti ini adalah konsep yang diperkenalkan oleh Jean Baudrillard yang mewakili tiada lagi batas antara yang nyata dan yang semu sehingga berdampak pada runtuhnya kehidupan sosial manusia karena tak mampu lagi bersosial diakibatkan oleh media. Kehidupan manusia akan terpecah menjadi individu-individu yang melakukan aktifitas yang tanpa disadari mereka saling menjauhi satu sama lain, danmengakibatkan kurang eratnya hubungan antar sesama secara langsung. Maka pada saat itu pula kehidupan sosial manusia mengalami keruntuhan yang diakibatkan oleh era komunikasi media simulkra.
\end{abstract}

Kata Kunci:RuntuhnyaDuniaSosial, Komunikasi Media, Simulakra

\section{A. Pendahuluan}

"Semua yang ada di dunia ini akan berubah, tidak ada yang abadi, kecuali perubahan itu sendiri" (Heiraklitus).

Hidup di dunia media populer hariinikitadiajakuntukmenyaksikan situasi,yakni suatu dunia yang lebih luas. Jika tanpa kejelian atau upaya untuk Tabayyun, maka kita dijejali denganberita-beritaHoaxbegitusaja. Masa kini, didominasiolehsimulasi, segala sesuatu tanpa ada rujukan aslinya. Manusia abad kontemporer hidup dalam ekstasi komunikasi yangkacau, seiring dengan lenyapnya 
ruang privat. Ruang publik tak lagi menjadi tontonan dan ruang privat tak lagi menjadi rahasia. Perbedaan antara bagian dalam dan bagian luar terhapus seiring dengan rancunya batas antara ruang publik dan ruang privat. Kehidupan yang paling intim, sekarang menjadi penopang hidup virtual media, kata Baudrillard.

Di sampingitu, globalisasi mendorong menipisnya batasbatas wilayah memasuki abad 21 . Semangat kapitalisme sejak revolusi industri membawa serta perubahan yang begitu masif hingga ke pelosok negeri. Mobilisasi alat transportasi dan teknologi komunikasi dan perkembangan modernisasi mendorong pergeseran pola-pola produksi menjadi pola konsumsi. Dibawah era kapitalis orientasinya pada Mode of Production dan sekarang adalah Mode of Consumption. Orientasi konsumsi yang semula ditujukan bagi necessary, menjadi life style. Sehingga semua aspek kehidupan manusia tidak lebih hanya sebagai objek. Fungsi-fungsi objek konsumer bukan pada nilai guna atau manfaat suatu barang atau benda, melainkan tanda atau simbol yang disebarluaskan melalui iklan-iklan gaya hidup masyarakat media. Dampak yang dapat kita amati adalah pergeseran motivasi mahasiswa antara meaning, function dan fun.
Kita sebut manusia tipe Meaning. Manusiasepertimemiliki aktifitas yangmenumbuhkansemangatuntuk belajar mempertanyakan segala sesuatu "apa makna dari semua ini? kemudian ditelitinya,ia mampu berfikir ilmiah serta meragukan halhal yang bersifat mistik. Ia tidak lagi merasakan dirinya terkepung oleh kekuatan-kekuatan gaib, takhayul, dongeng dan lain sebagainya. Ia secara bebas berfikir serta bertindak, ingin meneliti segala hal yang ada di alam raya.

Manusiatipe function.Manusia yang memilikiaktifitashanya sekedar mencari manfaat material semata, sepertiapamanfaat saya ke kampus? Ia berorganisasi, belajar membuat proposal, menduduki jabatan prestisius, membuat kegiatankegiatan fiktif guna mendapatkan keuntungan-keuntungan ekonomis. Mereka ini tidak lagi berorientasi pada pencarian ilmu pengetahuan "membaca, menulis, dan berdiskusi", melainkan memanfaatkan status mahasiswa sebagai sumber materi semata.

Dan terakhir kita sebut mahasiswa tipe fun. Manusia seperti ini memiliki aktifitas manakala ia berangkat ke kampus hanya untuk eksistensi semata, baik eksis di dunia nyata maupun di media sosial. Banyak dari mereka dengan sadar berfoto selfieatau memotret diri 
sedang belajar di kampus, sedang membaca buku, sedang berada di perpustakaan, di auditorium ketika seminar, workshop, wisuda. Mengupload foto-foto mereka seraya menulis, at kampus, at hotel, with prof,maaflagikhusyuq, kalo ada yang nyari gue cari di google. Segala kehidupan masyarakat kampus dipenuhi simulasi-simulasi layaknya film-film Hollywood, film korea, film india, film FTV, dan iklan-iklan gaya hidup.Perubahan besar-besaran ini merembes masuk ke sendi-sendi kehidupan kemudian mengaburkan antara realitas dengan hyper-realitas (melampaui kenyataan), inilah yang disebut oleh Jean Baudrillard dengan sebutan dunia simulakra.

\section{B. Berhala Kehidupan}

Pemikiran Baudrillard di pengaruhi oleh banyak filsuf besar terutama yakni Karl Marx, terutama dalam tema-tema seperti komuditas, nilai guna tukar, teori produksi, dan teori konsumsi. Kemudian Baudrillard mencoba meneliti masyarakat yang berfokus pada komunikasi massa yang semakin hari makin bertambah penggunanya. Baudrillard megubah teori nilai guna dan nilai tukar Marx menjadi nilai tanda. Baudrillard mengatakan bahwa konsumsi tidak terbatas. Kehidupan masyarakat dewasa ini sangat dipengaruhi dan ditentukan oleh konsumsi. Masyarakat akan lebih banyak mengkonsumsi dan menilai mayarakat lain dari seberapa besar ia mengkonsumsi, terutama yang telah disediakan oleh media. Tatanan seperti ini dinamakan sebagi hypercivilization dan masyarkatnya adalah masyarakat konsumen. ${ }^{1}$

Dunia menurut Baudrillard didominasi oleh simulakra. Dunia sepertiini adalah konsep yang diperkenalkan Baudrillard yang mewakili tiada lagi batas antara yang nyata dan yang semu. Dunia sekarang ini sudah menjadi dunia imajinasi. Baudrillard memberikan contoh Disneyland yakni segala sesuatu yang terjadi bersifat mimpi-mimpi, jauh dari realitas kehidupan manusia. Disneyland menurutBaudrillard merupakan berhala mutakhir. Pemujaan yang menunjukkan betapa irasionalnya perilaku konsumtif orang-orang yang rela mengantre berjam-jam membayar puluhan dollar hanya untuk memuaskan nafsu, insting, memenuhi kesenangan belaka. Simulakra adalah dunia penuh dengan alam maya, palsu, tiruan, semu dan kolektivitas yang muncul adalah semu. ${ }^{2}$ Segerombolan orang

1 Toeti Heraty Noerhadi, Berpijak Pada Filsafat: Kumpulan Sinopsis Disertasi Program Pascasarjana Filsafat Fakultas Ilmu Pengetahuan Budaya Universitas Indonesia, (Depok: Komunitas Bambu, 2013), 147.

2 Burhan M. Bungin, Sosiologi Komunikasi: Teori, Paradigma, dan Diskursus 
gembira menikmati kebersamaan mereka. Kemudian akan terpecah menjadi individu-individu yang melakukan aktifitas itu-itu saja, tanpa disadari mereka saling menjauhi satu sama lain, mengakibatkan kurang eratnya hubungan antar sesama secara langsung.Iklan, etalase, produk, merek, fashion, dan komuditas merupakan hal-hal yang diandalkan bagi kaum kapitalis. Lambat laun semua yang di sediakan akan di konsumsi masyarakat, dengan tujuan mendapatkan keuntungan sebesar-besarnya.

Apayangdikonsumsimasyarakat kita sekarang ini bukan lagi dalam bentuk kebutuhan yang nyata adanya, namun konsumsi dalam bentuk kesemuan, jauh dari realitas kehidupan. Tindakan dari konsumsi dapat dilihat dari hasil perubahan perilaku yang tidak disadari (memanipulasi)keinginanatauhasrat masyarakat untuk menyatakan diri secara bebas. Tujuan utama sistem produksi tidak pada kebutuhan masyarakat, namun bagaimana masyarakat memanipulasi dalam menyerap produk tersebut sebagai kekuatan konsumsi dan dalam kerangka kekuatan produksi global. Masyarakat akan di ajak menelusuri sesuatu yang bersifat abstrak. Kemudian akan ditumbuh

Teknologi Komunikasi di Masyarakat, (Jakarta: Kencana, 2006), 12-13. kembangkan dunia yang berbeda dengan dunia kenyataan.

Salah satu elemen penting dalam tindakan konsumsi masyarakat konsumen adalah iklan atau advertising. Keberadaan iklan yang disebar luaskan pada masyarakat akan membawa pengaruh besar dalam pengkonsumsiannya. Iklan yang menarik akan diburu masyarakat, meskipun terkadang iklan tersebut tidak masuk akal. Pengaruh media massa, ketika iklan hanya menampilkan tandatanda, di kemas sedemikian rupa hingga menembus panca indra kita, lalu kesadaran tertipu, hingga kita terperangkap dalam masyarakat konsumsi. Misalkan, salahsatuiklan susu yang menggambarkan bumi gersang, tandus, kering tidak ada sesuatu tanda-tanda kehidupan, tiba-tiba muncul naga warna putih, kemudian masuk kaleng, dan bumi tiba-tiba menjadi hijau dengan mahluk tumbuh-tumbuhan disekitarnya.

Bila dunia sudah dikuasi oleh kode-kode, keberadaan televisi kian signifikan, mempengaruhi aturan hidup masyarakat di palsukan secara tidak sadar. Televisi mulai menyebarkan iklan-iklan yang bukan lagi menjadi kebutuhan masyarakat, namun hal-hal yang dirasa tidak menjadi keperluan primer semakin di sebar luaskan. 
Masyarakat di sodorkan sesuatu hal yang tidak perlu, merek dari suatu barang misalnya. Kegunaan handphone misalnya, semua jenis HP fungsi utamanya adalah sebagai alat komunikasi, faktanya, masyarakat kita sekarang akan memburu merek HP yang sedang mendunia, zaman 90-an merek HP yang biasa dikenakan, Nokia, Motorolla, Sony, Blackberry dan yang lainnya. Karena perkembangan teknologi semakin canggih, merek HP terdahulu tergeserkan oleh merek-merek baru, keluaran masa kini seperti Samsung, I-Phone, Oppo, Lenovo, dan merekmerek baru lainnya. Masyarakatpun tergiurkan akan merek-merek HP terbaru, mereka akan membeli HP dengan merek terbaru. Mahasiswa pun ikut terseret arus perkembangan teknologi, mereka akan saling berlomba-lomba dalam mengkonsumsi HP pengeluaran terbaru. Yang paling tinggi merek Hpnya dianggap orang keren dan yang paling rendah merek HP-nya adalah kolot, kampungan. Ternyata tolak ukur dari seorang dikatakan keren adalah dari seberapa besar ia mengkonsumsi simbol-simbolbaru, semakin tinggi nilai konsumsinya maka distingsi kehidupan semakin memuncak.

Tatanan simulakra sebenarnya tidak hanya berkaitan dengan permainan tanda, akan tetapi juga menyangkut kekuasaan dan realisasi sosial, dimana yang berlaku adalah tanda yang murni namunkehilangan refrensinya. Tanda yang murni ini menghasilkan kekerasan simbolis dan metafisika kode. Pertanyaannya menyangkut tanda dan tujuan rasionanya tidak dibutuhkan lagi. Simulasi dan kode menarik seluruh realitas menuju hiper-realitas ${ }^{3}$ sehingga yang terjadi adalah dunia nyata dilenyapkan dan masyarakat lebih mengutamakan dunia maya. Masyarakat secara tidak sadar sudah tergeserkan solidaritas sesamanya. Yang jauh makin dekat dan yang dekat makin jauh. Tidak memperdulikan siapa yang disampingnya. Jasad memang berpijak di tempat, namun ruhnya jauh dalam dunia nyata. Sekarang ini masyarakat sudah tidak mengenali keaslian, karena dunia nyata sudah tergeserkan menjadi dunia yang penuh dengan khayalan.. Hal ini dapat mengakibatkan keberadaan seseorang yang menginjakkan kaki di dunia nyata mulai terabaikan. Mayarakat akan lebih menyoroti kehidupan penuh kepalsuan. Tidak saling mengenal satu sama lain, perhatian penuh terhadap dunia lain yang menimbulkan kurangnya hubungandalam realitas kehidupan.

3 Toeti Heraty Noerhadi, Berpijak Pada Filsafat ..., 154-155. 
Prinsip hiper-realisme simulasi menjadi prinsip utama kehidupan masyarakat. Simulasi yang menimpa masyarakat pada akhirnya akan menyebabkan implosi masyarkat. ${ }^{4}$ Bila itu terjadi, maka yang yang tertinggal dari masyarakat hanyalah massa. Massa yang bungkam merupakan khayalan atau bayangan. Kebungkaman dari massa di hidupkan oleh penggunanya, ia menunggu diekspos, media massa bisa mengubah atau merekayasa realitas dan memberinya tanda atau citra sesuai dengan kepentingan yang berada di belakang media massa itu.

Media massa dan budaya populer mempunyai kaitan yang sangat kuat. Secara singkat dapat dikatakan media massa sangat berpengaruh besar dalam tumbuh suburnya budaya populer. Kemajuan teknologi sedemikian pesat, hingga setiap harinya penduduk medsos semakin bertambah. Perkembangan media kian hari makin meruak khususnya pada negara-negara maju. Negara yang sudah maju sering kali menjadi patokan maupun sorotan utama dari negara-negara berkembang. Hasil dari kecanggihannya hanya bisa di konsumsi oleh masyarakat negara berkembang. Al hasil budaya yang ada di Barat atau negara berkembang tumbuh subur di negara berkembang. Budaya yang

$4 \quad$ Ibid., 158. populer biasanya akan di ukur dari kecanggihan teknologinya. Jadi, budaya-budaya yang ada di negara maju akan di terapkan di negara berkembang sebagai penilaian akan ketidak tinggalannya.

Masyarakat yang semakin hari hanya dijadikan konsumer belaka, terjerumus akan arus teknologi, tanpa ada rasa kesadarannya, dimanipulasi secara tidak langsung, namun masyarakat akan merasa nyaman dalam posisinya. Apa-apa saja yang diadakan oleh negara maju akan di aplikasikan. Secara tidak sadar mayarakat negara berkembang di Nina bobokkan. Terhanyut dalam drama dunia penuh kecanggihan. Media massa juga mampu memaksa subjek menjadi pasif. Setelah menjadi pasif, subjek akan acuh tak acuh terhadap tanda yang di tawarkan. Media massadengankecanggihannya mempu meracuni relung-relung kesadaran manusia. ${ }^{5}$ Manusia semakin jauh terbawa arus hingga ia akan terlupa dengan kehidupan realitasnya. Ketidak pandaian dari subjek akan berdampak sangat besar bagi kehidupannya. Subjek akan lebih memilih media khayalnya, dan melupakan media aslinya.

Ekstasi komunikasi juga menelanjangi ruang pribadi manusia dan menjadikan segalanya

$5 \quad$ Ibid., 161. 
menjadi urusan publik. Kesenangan akan dunia massa, lambat laun menimbulkan kegembiraan untuk mengotak-atik dunia pribadi manusia tanpa ada batasan. Kepuasan yang akan dirasa bila mana persoalanpersoalan diri pribadi sudah tidak perlu di tutup-tutupi, privasi bebas di sebarluaskan. Tidak akan ada lagi sesuatu yang menjadi kepribadian yang hanya diketahui oleh diri pribadi, namun semua perkara baik pribadi atau umum sudah menjadi topik pembicaraan setiap orang.

Hiper-lealitas merupakan realitas buatan, atas realitas asli tertentu. Melalui proses manipulasi realitas buatan itu terputus hubungannya dengan realitas aslinya. Kita terjebak, terperangkap dalam zona media massa. Kehidupan nyata manusia mulai teralihkan oleh dunia yang penuh kepalsuan, semu, khayal, imajinasi. Manusia mulai jenuh dengan kenyataan hidupnya dan akhirnya akan memilih arena yang membuatnya lebih nyaman dari kehidupan aslinya. Baudrilliad melukiskan kehidupan post-modern yakni kehidupan yang ditandai oleh simulasi, di mana manusia hidup di abad simulasi. ${ }^{6}$

Dengan dasar dunia yang sudah digitalisasi dengan kode

6 George Ritzer dan Douglas J. Goodman, Teori Sosiologi Modern, Edisi Ke-6, (Jakarta: Kencana, 2007), 640-641. sebagai realitas metafisisnya, maka sebernarnya realitas yang kita miliki hanya sebatas keluhan, yang kita menuntut diri lebih mengutamakan kehidupan palsu. Nonton film Korea, kita seakan-akan di ajak untuk menjelajahi kehidupan dunia ini yang penuh dengan kesenangan, seperti dunia ini sudah sangat sempurna. Dan tanpa disadari kita akan lebih bahagia bila sedang menyaksikannya. Perubahan zaman yang sedemikian rupa, kecanggihan teknologi semakin memuncak membawa pengaruh signifikan, mulai dari pengaruh positif maupun pengaruh negatif. Berbagai kalangan masyarakatpun dapat merasakan pengaruhnya, dari anak-anak, remaja, dewasa bahkan orang tua. Dari kalangan tingkat kelas atas maupun tingkat kelas bawah. Dari pelajar, mahasiswa, pejabat bahkan pemerintah sekalipun. Kecanggihan teknologi ini dapat di ukur dari seberapa banyak masyarakat menggunakannya.

Maraknya penggunaan sosial media atau yang biasa kita sebut sosmed, membuat masyarakat pada umumnya kecanduan akan media yangsatuini.Entahpengaruhnyayang sedemikian baiknya atau buruknya bagi pengguna. Terutama bagi mahasiswa, yang terkadang terbawa arus akan asiknya bermain sosmed. Keikut sertaan mereka membuat 